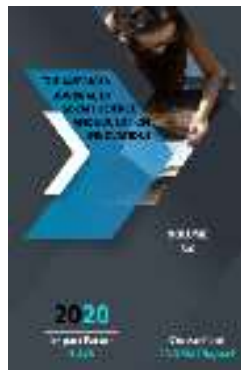

\title{
Main Directions Of Optimization Of Russian Language Teaching To Veterinary Students At University On The Basis Of Act
}

Journal Website: http://usajournalshub.c om/index,php/tajssei

\author{
Nazirova Zilola Rasulovna \\ Tashkent Branch SAMVMI, Russian Language Teacher, Uzbekistan
}

\begin{abstract}
Copyright: Original content from this work may be used under the terms of the creative commons attributes 4.0 licence.
\end{abstract}

\section{ABSTRACT}

The article deals with the use of modern information and communication technologies in the teaching of Russian language to students of veterinary specialties at the university. Information competence, which has become one of the main indicators of quality education, is one of the main conditions of modern education, the formation of which is directly related to the active participation of students in an open information and educational environment. Modern information and communication technologies allow you to develop unique didactic conditions and create regulation, in individual educational orbits.

\section{KEYWORDS}

Informatization of education, information and communication technologies, language and speech competence, individual educational trajectory, information competence, computer literacy.

\section{INTRODUCTION}

Informatization of education is a multi-stage, multi-dimensional process that involves not only the use of innovative teaching materials and ICT tools in the learning process, but also the promotion of specific criteria for digital information competence of teachers. 'includes. Information competence, which has become one of the main indicators of quality education, is one of the main conditions of modern education, the formation of which depends directly on the active participation of students in an open information and educational environment.

In modern lexicography, the term is defined as follows: "ICT includes various software and hardware tools based on computer 
technology, as well as modern means and systems of information exchange that provide the collection, storage, production and transmission of information." [1]. The definition of ICT has many formulas, but in the context of the problem under analysis, the main one is their use as a set of network technologies, techniques and software tools designed and used to collect, analyze, store and disseminate data. to understand

The organization of classes using ICT in the teaching of Russian language to students of veterinary specialties demonstrates the progress of education, firstly, their integration into the educational process significantly accelerates the continuity of social experience and knowledge from generation to generation; second, ICT helps students to be more active and successful in adapting to changes in the field of social Russian; third, the use of ICT in the education system allows for the renewal and "modernization" of education in accordance with the social order of society. In addition, the chosen subject area is mastered by students at different levels, skills and competencies in solving common practical problems are developed, decision-making speed in non-standard problem situations and skills in certain types of activities are developed. [2]

The process of informatization of higher education is carried out with the help of electronic educational resources, information systems of the Republic. The analysis of methodological literature [3] identified the following advantages of the use of ICT in the teaching of Russian (foreign) language to students of veterinary specialties: improving the quality and efficiency of the educational process; increase the activity of students' educational activities; implementation of interdisciplinary links; increase the volume and optimize the search for the required information; creating a unique educational environment for students, taking into account their level of knowledge and individual trajectory.

It is known that this is not the formation of topics through ICT tools used in language learning, but the implementation of multiplatform courses on individual skills (lexical and grammatical, phonetic) or duration (speaking, reading, writing, listening) side trend [4] when the teacher is creating and using multiple sites at the same time. The detrimental side of the fragmentation of technologies is that the conceptual approach to teaching Russian (foreign) language is violated, as not all authorial developments are widely used.

The basis of the analysis showed that the organization of lessons through technological means leads to the following positive methods:

- Interactivity (changing content or communication method),

- Advertising (remote online communication and public publication);

- multimedia (use of materials in different formats: text, audio, photo, video);

- Hypertext structure (creation of hyperlinks and clicking on active links). [3]

One or more information systems (LMS, $M O O C$ ), ICT activities using training to create a learning environment. In addition, information systems have the following pedagogical capabilities:

- ICT tools for close communication between students and teachers, testing and monitoring of students and results, interactive information interaction between students to create a single research project;

- Provide systematic support to teachers for students of all levels, including distance learning groups.

- Individualization and differentiation of the learning process (gradual formation and development of all Russian language teaching skills that make up the system 
and the development of Russian speaking skills for students' professional activities);

- Visualization of educational information (replacement of textual content with audiovisual);

- Unlimited performance of educational tests in the process of mastering the material and self-education of students;

- Development of communication skills (formation of speaking skills for written and professional activities);

- Intensification of all levels of the educational process; deepening interdisciplinary ties;

- Improving the information and methodological support of pedagogical activities (high level of information updating);

- Compile data according to the selected curriculum. [3]

- In order to increase the efficiency of the organization of the educational process, it is necessary to involve information and communication technologies, which are the main directions for optimizing the teaching of foreign languages in non-ICTbased language universities. [5]

- The first direction of ICT-based optimization for veterinary students is the creation and use of a system of continuous teaching of the Russian language, the formation of an information and educational environment.

- The second direction of optimizing the teaching of Russian language on the basis of ICT in non-linguistic (for students of veterinary specialties) university is the implementation of content design (LMS or MOOC).

- In practical training in a foreign language, the principle of interdisciplinary communication is implemented in the process of solving practical problems in the specialty. At the same time, ICT tools allow: individual integration of topics in the specialty of students and the selective use of diagnostic, training and testing programs, as well as e-learning resources; use hypertext presentation of topic information; search, analysis, generalization, etc. of professional information should be provided.

- Thus, theoretical and practical interdisciplinary connections can be identified. At the same time, theoretical subject connections are made between students through the availability of knowledge in different fields and areas. The formation and development of practical interdisciplinary communication occurs through the skills of speech activity in Russian: th language ability to listen and speak, the ability to read and write-speech ability.

- The fourth direction of optimizing foreign language teaching based on ICT is the implementation of various forms of monitoring and evaluation. Information and communication technologies significantly expand the opportunities for tracking and evaluating student achievement.

- From a methodological point of view, ICT requires students to conduct formative or formative assessment when assessed in the course of a task in order to encourage self-management and selfcorrection and to help them better master the material. allows. The ability for students to organize mutual evaluation of each other's work is very important, for example, when teaching writing and speaking skills [7].

- In conclusion, we note that the methodologically well-organized learning process of the Russian language for students of veterinary specialties implies an optimal combination of information technology and traditional teaching methods at all stages of education. The use of ICT allows to improve and differentiate education, to take into account the individual characteristics of 
students and to motivate them to further independent work.

- Various information systems aimed at the formation and development of all the basic skills of speech activity in a foreign language contribute to the process of optimizing the system of teaching Russian language WMD (foreign language) at the university.

\section{REFERENCES}

1. New dictionary of methodical terms and concepts (theory and practice of writing). [Electronic resource]. - URL: method terms. academic.ru

2. Taramova, E.A. Problems and perspectives of the use of ICT in higher education // Actual tasks of pedagogy: materials VI Mejdunar. nauch. konf. (g. Chita, January 2015). - Chita: Izdatelstvo Molodoy uchenyy, 2015. S. 156.

3. Burimskaya D. V., Kharlamenko I. V. Kompleksnyy podkhod pri obuchenii studentov neyazykovyx fakultetov inostrannomu yazyku na baze informatsionnyx sistem // Vestnik Moskovskogo gosudarstvennogo oblastnogo Universiteta. Series: Pedagogy. 2019. № 2. S. 96-111.

4. Kuznetsov A. A. Modeling and realization of multiplatformennyx online courses // Modern information technologies and IT education. 2016. T. 12. № 3-1. S. 75-81.

5. Burimskaya D. V. Training of students in foreign languages on the basis of ICT // Informatsionnoe obshchestvo. 2017. № 6. S. 61-67.

6. Zolotova M. V., Ganyushkina E. V. Formation of skills of an autonomous student in English in the process of project deyatelnosti // Bulletin of the Nizhny Novgorod State Linguistic University. N. A. Dobrolyubova. 2016. Vyp. 35. S. $138-145$.

7. Titova S. V., Kharlamenko I. V. Method sovmestnogo napisaniya esse i ix vzaimnogo otsenivaniya pri obuchenii pismenno-rechevym umeniyam // Vestnik
Moskovskogo Universiteta. Series 19. Linguistics and intercultural communication. 2017. № 3. S. 26-40.

8. Kazakova, T.A. Ispolzovanie informatsionno-kommunikatsionnyx tehnologiy $v$ protsesse prepodavaniya inostrannogo yazyka $v$ vuze // Lingvistika i mejkulturnaya kommunikatsiya. - 2015. Issue №3 (17). - S. 78.

9. Sovremennye informatsionnye $i$ kommunikatsionnye teknologii: didakticheskie svoystva i funktsii. [Electronic resource]. - URL: cyberleninka.ru. 